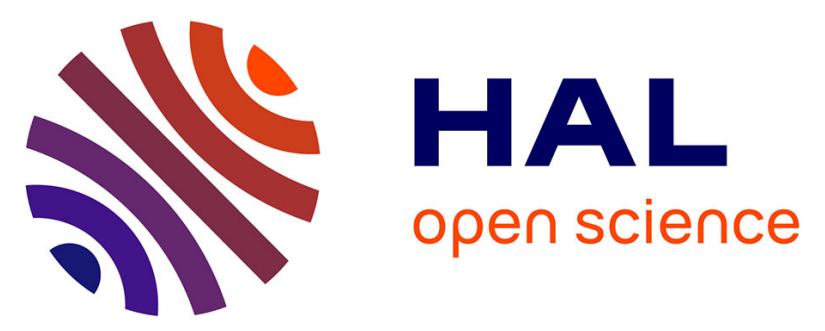

\title{
Endotoxin concentration in poultry houses for laying hens kept in cages or in alternative housing systems
} Adeline Huneau-Salaün, Sophie Le Bouquin, Valérie Bex-Capelle, Didier Huonnic, Loïc Balaine, Marie-Thérèse Guillam, Fabrice Squizani, Claire Ségala, Virginie Michel

\section{To cite this version:}

Adeline Huneau-Salaün, Sophie Le Bouquin, Valérie Bex-Capelle, Didier Huonnic, Loïc Balaine, et al. Endotoxin concentration in poultry houses for laying hens kept in cages or in alternative housing systems. British Poultry Science, 2011, 52 (05), pp.523-530. 10.1080/00071668.2011.617728 . hal00745615

\section{HAL Id: hal-00745615 \\ https://hal.science/hal-00745615}

Submitted on 26 Oct 2012

HAL is a multi-disciplinary open access archive for the deposit and dissemination of scientific research documents, whether they are published or not. The documents may come from teaching and research institutions in France or abroad, or from public or private research centers.
L'archive ouverte pluridisciplinaire HAL, est destinée au dépôt et à la diffusion de documents scientifiques de niveau recherche, publiés ou non, émanant des établissements d'enseignement et de recherche français ou étrangers, des laboratoires publics ou privés. 


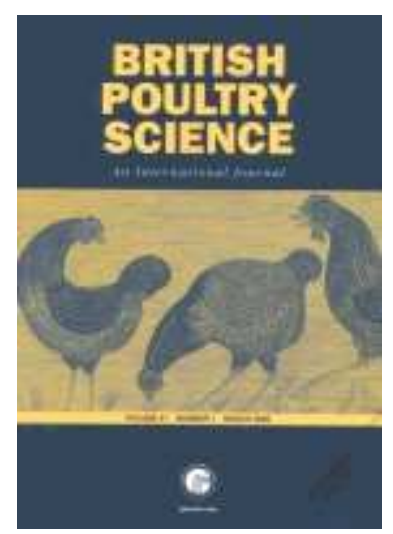

\section{Endotoxin concentration in poultry houses for laying hens kept in cages or in alternative housing systems}

\begin{tabular}{|r|l|}
\hline Journal: & British Poultry Science \\
\hline Manuscript ID: & CBPS-2010-306.R1 \\
\hline Manuscript Type: & Original Manuscript \\
\hline Author: & $16-$ Dec-2010 \\
\hline & $\begin{array}{l}\text { Complete List of Authors: } \\
\text { Buonnitted by the } \\
\text { Bulaine, Loïc; Anses, UEBEAC } \\
\text { Guillam, Marie-Thérèse; SEPIA-Santé } \\
\text { Squizani, Fabrice; LHVP } \\
\text { Ségala, Claire; SEPIA-Santé } \\
\text { Michel, Virginie; Anses, UEBEAC }\end{array}$ \\
\hline Keywords: Adeline; Anses, EBEAC & Laying hens, dust, endotoxin \\
\hline \multicolumn{2}{|l}{} \\
\hline
\end{tabular}

\section{SCHOLARONE ${ }^{m}$ Manuscripts}


Anses-French Agency for food, environmental and occupational health safety, BP 53

10 Route de Beaucemaine, 22440 Ploufragan France; ${ }^{1}$ LHVP-Laboratory of Hygiene of

11 Paris, 11 rue Georges Eastman, F-75013 Paris, France; and ${ }^{2}$ SEPIA-Santé, 31 rue de

\section{Running title:}

Endotoxin concentrations in henhouses

Accepted for publication: 15th Jan 2011

Correspondence to: Adeline Huneau-Salaün, Anses, BP 53, F-22440 Ploufragan, France. Tel: + 3329601 
22 Abstract 1. Endotoxins as components of organic dust may have adverse effects on the

23

24 25 respiratory health of workers in poultry buildings. The move towards more welfarefriendly housing systems for layers may increase worker exposure to air contaminants due to the use of litter.

2. The endotoxin concentrations in the inhalable fraction of airborne dust (below 100 $\mu \mathrm{m})$ from cage and alternative system houses (on-floor, free range and aviaries) were compared under both experimental and commercial conditions.

3. The endotoxin concentration was higher in experimental aviaries (median: 565 $\mathrm{EU} / \mathrm{m}^{3}$, range: $\left.362-1491 \mathrm{EU} / \mathrm{m}^{3}\right)$ than in cage housing $\left(98 \mathrm{EU} / \mathrm{m}^{3}(51-470)\right)$.

4. In field conditions, the endotoxin concentration in the air of 13 alternative houses was higher ( 35 to $3156 \mathrm{EU} / \mathrm{m}^{3}$ ) than in cage system buildings $\left(\mathrm{n}=8,78-576 \mathrm{EU} / \mathrm{m}^{3}\right.$ ). It was correlated to the respirable dust concentration (fraction below $5 \mu \mathrm{m}$ ) and to the temperature inside the henhouse but no seasonal variation was observed.

5. The present study emphasises that considerable worker exposure to endotoxins may occur in laying houses, especially in alternative systems.

\section{INTRODUCTION}

The high frequency of respiratory health problems among workers in poultry confinement buildings has often been reported (Radon et al., 2002b; Kirychuck et al., 2003; Rylander and Carvalheiro, 2006). The air in poultry houses is known to be contaminated by various potentially hazardous materials including gases (e.g. $\mathrm{NH}_{3}$ ), chemicals such as disinfectants, and organic and inorganic dust. Organic dust in poultry houses consists of a complex combination of feed, litter, animal material such as 
46 feathers and skin, and faecal particles (Ellen et al., 2000). It also contains high 47 concentrations of airborne microorganisms such as fungi, viruses, bacteria, and their constituents (Jones et al., 1984; Seedorf et al., 1998; Radon et al., 2002a; Lee et al., 2006). Endotoxins, derived from the outer membrane of Gram negative bacteria, constitute a major component of organic dust (Rylander, 2002). Endotoxins exhibit proinflammatory properties and are therefore implicated in the aetiology of occupational lung diseases including asthma-like syndrome, organic dust toxic syndrome (ODTS) and chronic airway obstruction (Schenker et al., 1998; Rylander, 2002; Douwes et al.,

54 2003). High levels of endotoxins in poultry confinement buildings have been reported

55 (Clark et al., 1983; Jones et al., 1984; Seedorf et al., 1998; Schriel et al., 2007). A relationship between poultry worker exposure to endotoxins and the occurrence of

57 respiratory symptoms has been established in some studies (Thelin et al., 1984;

58 Donham et al., 2000; Kirychuck et al., 2006). In laying hen and turkey buildings an 59 exposure concentration higher than $614 \mathrm{EU} / \mathrm{m}^{3}$ endotoxins was associated with 60 pulmonary function decrements in workers (Donham et al., 2000). Interestingly, aerial 61 concentrations of endotoxins and their consequences on human health appear to vary according to the bird housing system. Kirychuk et al. (2006) reported that endotoxin concentrations in cage-housed poultry farms tended to be greater than in on-floor broiler

64 farms, and that workers in cage systems more frequently reported current and chronic 65 phlegm. In experimental layer houses, Larsson et al. (1999) observed that exposure to 66 airborne dust from on-floor houses induced a more acute inflammatory reaction in the 67 upper airways of naïve subjects than exposure to dust from cage system houses. This was related to higher concentrations of inhalable dust and ammonia, but not of endotoxins, in the air of the non-cage buildings. However, these studies have not 
70 completely taken into account recent developments in hen housing systems, especially

71 in Europe. Indeed, to improve animal welfare, the European Directive 1999/74/EC

72 requires the abolition of conventional cages for housing laying hens from 2012 73 onwards. Alternatives such as furnished cages with litter or loose systems have been

74 proposed. In France, $80 \%$ of laying hens are still kept in cages but conventional cages

75 are gradually being replaced by furnished cages which include a nest box, a pecking and

76 scratching area with litter, and $15 \mathrm{~cm}$ of perch per bird. The most common alternative

77 system in France is the on-floor henhouse in which the building is divided into a slatted 78 area with perches and nest boxes, and a litter area. The development of housing systems

79 where hens can move freely and are provided with litter seems to lead to an increase in 80 airborne dust concentration, but few comparisons of cage and alternative hen housing 81 systems have been carried out since the adoption of the European Directive for the 82 protection of laying hens (Protais et al., 2003; de Reu et al., 2009; Nimmermark et al., 83 2009). There is therefore a lack of data to assess the impact of housing system 84 modifications on the working environment. Thus a French epidemiological study, called 85 AIRPOUL project, was carried out to characterise more precisely the air quality and 86 worker exposure to aerial dust in cage and alternative systems for laying hens. This 87 project was based on an experimental assay, followed by an observational field survey. 88 The experimental assay was focused on measuring the personal exposure of workers to 89 air pollutants, while the field study assessed air quality in poultry buildings under 90 commercial conditions. The first objective of the present study, within the framework of 91 the AIRPOUL project, was to determine the personal exposure to endotoxins of 92 stockmen working in a cage system and an aviary system under experimental 93 conditions. Secondly, the ambient endotoxin concentrations were determined and 
94 compared with cage and on-floor buildings for laying hens under commercial conditions.

96

\section{MATERIALS AND METHODS}

\section{$98 \quad$ Experimental trial}

Experimental facilities

100 The study was performed in 2006 in two laying houses on an experimental farm located 101 in Brittany (France). In the first building, hens were kept in two identical aviaries 102 separated by a wire netting fence. Each aviary consisted of platforms on three levels and 103 housed 2,680 hens at a density of 9 hens per $\mathrm{m}^{2}\left(409 \mathrm{~cm}^{2}\right.$ of litter per hen). The second 104 poultry-house was equipped with three batteries of cages on three levels. The cages 105 were conventional with 5 birds per cage $\left(580 \mathrm{~cm}^{2}\right.$ per hen). There were 5760 hens. A 106 high-extraction forced ventilation system operated in both buildings. Hens and 107 husbandry management (feeding, watering and lighting programs) were the same in 108 both the cage and aviary houses.

109

110 Endotoxin and dust sampling.

111 The endotoxin concentrations in the inhalable dust fraction (diameter $<100 \mu \mathrm{m}$ ) were 112 measured 7 times in the ambient air when the hens were between 59 and 66 weeks of 113 age. The air sampler for endotoxin sampling (CAP 10, ARELCO, Auxerre, France) was 114 placed $1.5 \mathrm{~m}$ above the ground in the middle corridor of the cage building, and near the 115 separating fence at the height of the second platform in the aviary house. The air flow 116 was 1 1/min as specified by the manufacturer and was checked before and after sampling 117 with a soap bubble flowmeter (BUCK Calibrator M5, ARELCOA 5\% change of flow 
118 rate between the two measurements was considered acceptable. Sampling took place

119 from $0800 \mathrm{~h}$ to $1600 \mathrm{~h}$ during the same working day in both the cage building and 120 aviary house. Personal exposure to endotoxin of the workers taking care of the birds 121 was assessed three times during the same period. The workers wore the air sampler in 122 the breathing zone during a 6-hour work shift. During this period, their main activities 123 were collecting and sorting eggs, and making bird and mortality checks. Endotoxin samples were collected on $37 \mathrm{~mm}$ diameter glass fibre filters with a pore size of $0.5 \mu \mathrm{m}$ (Millipore AP4003705, St Quentin, France), aseptically placed in three-part polystyrene filter holders (Millipore M000037AO) in a constant airflow pump (SKC 224-PCTX8, ARELCO) operating at a rate of $11 / \mathrm{min}$ (air flow checked before and after measuring). The two workers involved in the study were non-smokers; one worked in the cage building and the other in the aviary system. Neither suffered from chronic respiratory diseases.

Ambient dust was measured fortnightly when hens were 19 to 63 weeks old.

132 Samples for the respirable dust fraction $(<5 \mu \mathrm{m})$ were collected using a stationary sampler (CAP 10, ARELCO), equipped with a pre-weighed filter with a pore size of 4 $\mu \mathrm{m}$. The samplers were located in the same places as the stationary air samplers for endotoxin sampling. They ran for about $8 \mathrm{~h}$ during the day of measurement. The suction pump was operated at a rate of $10 \mathrm{l} / \mathrm{min}$ and was checked before and after sampling. All

137 exposed filters were subsequently reweighed (AG 104, Mettler Toledo, Viroflay, 138 France) after desiccation for $12 \mathrm{~h}$ at $37^{\circ} \mathrm{C}$. The results were calculated according to air 139 volume and expressed as $\mathrm{mg} / \mathrm{m}^{3}$.

\section{Field trial}


142

143

144

145

146

147

148

149

150

151

152

153

154

155

156

157

158

159

160

161

162

163

164

165

Farm sample

The field study was carried out in 2008 on a sample of 21 laying houses stratified according to housing system: 8 poultry houses where hens were kept in cages, and 13 buildings where they were housed in an alternative system. Ten of the 13 alternative farms were specialised in free-range production, and in the remaining three houses the hens were housed in aviaries. Farms were selected according to the willingness of the owners to participate in the study. The main characteristics of these farms are shown in Table 1. Cage buildings were characterised by their large size and forced ventilation system, whereas the smaller poultry houses in free-range systems were equipped with a natural ventilation system. The cages on two farms were furnished with a nest box and perches. The aviary systems differed from the other alternative systems in that they had a higher rearing density: median density of 13.6 hens/available $\mathrm{m}^{2}$ (min: 13.1 - max: 18.5) versus 7.9 (5.7-10.7) in the free-range systems; a forced ventilation system; a manure disposal system with belts; and no access to an open-air range.

\section{Table 1 near here}

\section{Dust and endotoxin sampling.}

One stationary sample of the respirable dust fraction and one stationary sample of the inhalable endotoxins were collected twice from each poultry house: once during the autumn/winter period (from October to March) and once during the spring/summer period (from April to September). Thus, two dust samples and two endotoxin samples were taken on each farm with the exception of two free-range farms and the three aviaries, which were only visited once during the autumn/winter period. This was due to veterinary problems in the two free-range farms in the spring/summer period; and to the fact that the three aviaries were recruited for the study later than the other farms. The 
166

167

168

169

170

171

172

173

174

175

176

177

178

179

180

181

182

183

184

185

186

187

188

189

endotoxin and dust samples were collected using the same methods as those used for ambient air in the experimental assay. No personal exposure measures for endotoxins were performed in the field study because the equipment required for this was too cumbersome to be worn by the farmers during a working day under field conditions.

\section{Endotoxin analysis}

At the end of sampling, the filters were sent in their holders to the Laboratoire d'Hygiène de la Ville de Paris and stored at $4^{\circ} \mathrm{C}$. Within $48 \mathrm{~h}$ of sampling, the endotoxins were extracted with $5 \mathrm{ml}$ of pyrogen-free water in borosilicate vials by shaking them horizontally $(1500 \mathrm{rpm})$ at room temperature for $60 \mathrm{~min}$. The extracts were centrifuged at $1000 \mathrm{~g}$ for $15 \mathrm{~min}$ in borosilicate tubes, and the supernatants were then analysed. Endotoxin analysis was performed using a microtitre plate (Falcon, 96 flat bottomed, sterile wells) with a quantitative kinetic chromogenic Limulus Amoebocyte Lysate (LAL) test (Endosafe, Charles River, L'Arbresle, France). $100 \mu 1$ of LAL reagent was added to each $100 \mu 1$ sample. The plate was then incubated at 37 $+/-1^{\circ} \mathrm{C}$ in a spectrophotometer (Sunrise, Tecan, Männedorf, Switzerland) and the optical density was read kinetically at $405 \mathrm{~nm}$ every minute. Each sample value was compared to a standard curve. Escherichia coli strain O55:B5 endotoxin (CSE Lot: EX51722; LAL Reagent Lot: V2702E; potency 17 endotoxin units (EU) per ng) was used to construct the standard curve. Data were analysed using Endoscan software. Inhibition and enhancement phenomena were checked by adding a defined amount of standard endotoxin to each sample. These interferences were reduced by serial dilution of the sample (e.g. full-strength, 1:10 and 1:100). The endotoxin analysis followed the European Standard EN 14031 (2003). Results were expressed in EU per cubic metre of 
190 air $\left(\mathrm{EU} / \mathrm{m}^{3}\right)$. The detection limit was $0.005 \mathrm{EU} / \mathrm{ml}$ and the upper limit of the standard 191 curve was $50 \mathrm{EU} / \mathrm{ml}$. A value of half that of the detection limit $(0.0025 \mathrm{EU} / \mathrm{ml})$ was 192 assigned to samples with concentrations below the detection limit. Given that sampling 193 and analysis required the use of pyrogen-free material, the polystyrene filter holders 194 were cleaned by sonication in $0.05 \%$ o triethylamine for $10 \mathrm{~min}$, rinsed three times in 195 pyrogen-free water and dried at $50^{\circ} \mathrm{C}$ in an oven. The glass fibre filter and glassware 196 were heated at $250^{\circ} \mathrm{C}$ for $90 \mathrm{~min}$. Each set of 20 filter holders and filters was tested in 197 order to exclude sets with endotoxin levels higher than the detection limit. Blank field 198 filters were used as controls for endotoxin contamination during transport and sampling 199 at each sampling campaign.

200

\section{Statistical analysis}

202 The data collected in the field study were not normally distributed and therefore results 203 are presented as median and range. Seasonal effect and correlation between respirable 204 dust concentrations and endotoxin concentrations were assessed using rank-based tests 205 (Spearman coefficient for correlation analysis, Kruskal-Wallis test for rank 206 comparison). The 5 farms where measures were obtained only during the autumn/winter 207 period were excluded from the seasonal-effect analysis (Wilcoxon test for rank 208 comparison on paired data). One sample, taken from a cage house during the 209 spring/summer period, was invalidated due to the high blank concentration and 210 consequently, this farm was also excluded from the seasonal effect study. Statistical 211 calculations were performed with SAS® 9.1 software.

\section{RESULTS}




\section{Experimental trial}

215 The endotoxin concentrations in the ambient dust samples obtained from the aviary 216 house were higher than in samples from the cage building for all but one of the 217 sampling days (Table 2). The median endotoxin concentration was thus higher $(P<0.05)$ 218 in the air of the aviary house than in the cage house. Consequently the median exposure 219 of workers to airborne endotoxins was at least three times lower in the cage system than 220 in the aviary system for a $6 \mathrm{~h}$ work shift. Similarly, the ambient dust concentration was 221 lower in the cage system than in the aviary system for all 23 days of measurements 222 (Figure 1).

\section{$224 \quad$ Field trial}

225 The median respirable dust concentrations and endotoxin concentrations in each 226 housing system are given in Table 3. As expected, the respirable dust concentrations 227 were higher $(P<0.01)$ in the alternative farms than in the cage farms, especially in the 228 three aviaries. The measurements showed great variability in the alternative systems 229 compared with the cage system. As shown in Figure 2, the endotoxin content of 230 inhalable dusts was also higher and more variable in the alternative than in the cage 231 houses: the median concentration was $684 \mathrm{EU} / \mathrm{m}^{3}(35-3156)$ in the alternative systems 232 compared with $204 \mathrm{EU} / \mathrm{m}^{3}(78-576)$ in the cage systems $(P<0.01)$. No seasonal effect 233 was observed on respirable dust concentrations or on endotoxin concentrations (Table 234 4), although the temperatures measured inside the buildings were actually lower during 235 the autumn/winter period than during the spring/summer period: the median of the 236 average temperature inside the buildings was $19.0^{\circ} \mathrm{C}(10.2-23.2)$ during the 237 autumn/winter period compared with $21.7^{\circ} \mathrm{C}(16.8-23.7)$ during the spring/summer 
period $(P=0.03)$. The inhalable endotoxin concentration was positively correlated to the respirable dust concentration (Spearman coefficient $\mathrm{r}=0.53, P<0.01$ ) and was negatively correlated to the average temperature inside the poultry house during the sampling 241 period $(\mathrm{r}=-0.40, P<0.01)$.

DISCUSSION

244

This study shows that high dust and endotoxin concentrations can occur in the air of experimental and commercial laying houses. The endotoxin concentrations in the ambient air, and to which workers were exposed, appeared to be high in comparison with the threshold of $50 \mathrm{EU} / \mathrm{m}^{3}$ over $8 \mathrm{~h}$ proposed by the Dutch Expert Committee on Occupational Standards. The American International Commission on Occupational Health (Schenker et al., 1998) identified that short-term exposure to concentrations less than $10 \mathrm{ng} / \mathrm{m}^{3}$ (100 EU/m3 assuming a conversion factor of $10 \mathrm{EU} / \mathrm{m} 3$ for $\left.1 \mathrm{ng} / \mathrm{m} 3\right)$ had no impact on workers' health, while a concentration above $10 \mathrm{ng} / \mathrm{m}^{3}$ was associated with inflammatory symptoms of the airways; a concentration above $100 \mathrm{ng} / \mathrm{m}^{3}$ (1000 EU/m3) with systemic effects on health; and a concentration higher than $200 \mathrm{ng} / \mathrm{m} 3$ (2000 EU/m3) with ODTS. The effect of exposure to endotoxins on the health of stockmen, particularly in alternative housing systems, may thus give cause for concern

257 because the common concentration limits (not specific to poultry working 258 environments) are regularly exceeded in these buildings. However, the exposure259 response threshold of $614 \mathrm{EU} / \mathrm{m}^{3}$ for workers in a poultry environment, proposed by 260 Donham et al. (2000), only appeared to have been exceeded for one working day in the 261 aviary system. Indeed, the exposures of workers to endotoxins in the experimental 
262 assay, even in the aviaries $\left(181-667 \mathrm{EU} / \mathrm{m}^{3}\right)$, were lower than those reported in a 263 previous experimental study (83-175 ng/m3 or 830-1750 EU/m3) (Larsson et al., 1999).

264 For the field study, stationary rather than personal sampling was chosen to determine 265 the exposure of both workers and animals. Indeed, deterioration of air quality may also 266 have an impact on poultry health (Michel and Huonnic, 2003), although no critical 267 concentrations of organic dust or endotoxins in the air have been established for 268 livestock. However, the stationary sampling method might lead to an underestimation of 269 human exposure to airborne endotoxins, because workers are close to endotoxin sources 270 and can even handle them during cleaning operations (Renström, 2002). Therefore, the 271 endotoxin measurements obtained by stationary sampling in our study cannot be 272 compared with the personal exposure measurements performed in studies designed 273 solely to assess human exposure. Furthermore, the endotoxin concentrations in the 274 ambient air, observed in both parts of our study, were lower than the average 275 concentrations measured with stationary samplers in 43 laying houses by Seedorf et al. 276 (1998) $(860 \mathrm{ng} / \mathrm{m} 3$ or $8604 \mathrm{EU} / \mathrm{m} 3)$; or the concentrations reported by Schriel et al. 277 (2007) in three on-floor houses $\left(3,389 \mathrm{UE} / \mathrm{m}^{3}(100-21933)\right)$. These comparisons have to 278 be considered with caution because endotoxin analysis methods may differ from one 279 study to another, although Schriel et al. (2007) also used the European Guideline EN 28014031.

281 A multicentric European survey under commercial conditions reported a 282 deterioration of air quality in alternative systems compared to cage systems for dust 283 concentrations (Takai et al., 1998) and endotoxin concentrations (Seedorf et al., 1998).

284 However, these studies date from the early 1990s, before the implementation of 285 Directive 1999/74/EC, which is likely to have led to substantial modifications to 
286 housing systems in Europe and to have altered air quality in poultry houses. Our study

287 thus confirms that air quality may deteriorate after the adoption of modern alternative 288 housing systems which comply with the recent European regulation. Differences in dust 289 and endotoxin concentrations between the cage and alternative systems may be due to 290 the presence of litter and to the greater activity of the hens in the on-floor buildings. In 291 addition, the natural ventilation systems in the alternative houses, in contrast to the 292 forced ventilation systems in the cage buildings, could lead to a lower ventilation rate 293 and thus a lower clearance rate of air-borne dust and endotoxins. For example, higher 294 concentrations of bacteria and gases were found in the air of poultry houses with 295 ventilation through porous inlets than in buildings equipped with automatic ventilation 296 systems (Radon et al., 2001).

297 As described in previous studies of personal exposure of poultry workers to 298 airborne dust and endotoxins (Thelin et al., 1984; Simpson et al., 1998a; Simpson et al., 299 1998b; Donham et al., 2000), a strong correlation between dust and endotoxin 300 concentrations was observed in the field studies, although the endotoxins were 301 measured in the inhalable fraction, and not in the respirable fraction as for dust. 302 According to Simpson et al. (1998b), this correlation may be difficult to demonstrate in 303 personal exposure studies as the endotoxin concentrations in dust could vary in the 304 different rooms and sites where people were working during the sampling period. This 305 problem does not occur in ambient exposure studies with stationary samplers. The 306 correlation between dust and endotoxin concentrations in layer houses could be useful 307 for implementing monitoring programs and corrective measures; assessment of 308 exposure could be limited to measurements of dust concentration, and control measures 309 taken to reduce dust concentration should also reduce the endotoxin concentration. High 
310 ventilation rates dilute dust concentration inside the house, but reduce ambient

311 temperature leading to thermal discomfort for birds and to discharge of airborne

312 pollutants in the environment. Various methods of air treatment to reduce dust

313 concentrations (physical and electrical filtration) have been tested with success under

314 experimental conditions (Lyngtveit and Eduard, 1997; Mitchell et al., 2000; Ellen et al.,

315 2010). However, their application in commercial conditions is difficult on account of

316 the large volumes of air to be treated. In contrast, spraying oil or fogging with water

317 droplets are inexpensive and effective methods which are relatively easy to use in

318 commercial poultry houses. A 50\% reduction in airborne dust concentration in an aviary

319 was obtained using water fogging without deterioration in the condifions of the hens'

320 feathers (Gustafsson and Von Wachenfelt, 2006). Local manual application of oil on

321 litter of an experimental aviary gave a reduction of 20 to $30 \%$ of fine dust emissions,

322 but no effect was observed when oil was applied with an automatic system (Ellen et al.,

323 2010). This technique has thus to be improved before being used under commercial

324 conditions.

$325 \quad$ No differences in dust or endotoxin concentrations were observed in our field

326 study between the measures obtained during the autumn/winter period and during the

327 spring/summer period. This result is in line with the observations of Seedorf et al.

328 (1998). By contrast, Schriel et al. (2007) noted a higher concentration of endotoxins in

329 the dust samples taken in winter than in those taken in summer and spring. Although the

330 seasonal effect was not significant in our study, a negative correlation was observed

331 between the average temperature inside the house and the endotoxin concentration. The

332 temperature inside the building, and the ventilation control measures taken in response 
333 to this temperature, are likely to influence the endotoxin concentration more than the 334 season.

335

The present study highlights that considerable exposure to endotoxins may occur 336 in laying houses under both experimental and field conditions. The personal exposures

337 to endotoxins recorded in the experimental houses exceeded the limits proposed by the 338 Dutch Expert Committee on occupational standards on all measurement days, and thus 339 give grounds for concern about the health of poultry workers. Effective methods to 340 reduce worker exposure to air contaminants in laying houses still need to be developed.

341 Higher dust and endotoxin concentrations were measured in alternative housing systems 342 than in cage houses under commercial conditions. Therefore further research is required 343 to focus on working conditions in these alternative systems because of the ban on 344 conventional cages in European Union from 2012.

345

348 The authors are grateful to the Experimental Services for Poultry and Rabbit Husbandry 349 of Anses, and to the egg production companies and farmers who collaborated in this 350 study. Funding for the AIRPOUL project was provided by the Conseil Régional de
346

347 351 Bretagne.

\section{ACKNOWLEDGEMENTS}

352 
REFERENCES

354

355 CLARK S., RYLANDER R. \& LARSSON L. (1983) Airborne bacteria, endotoxin and fungi in 356 dust in poultry and swine confinement buildings. American Industrial Hygiene Association 357 Journal, 44: 537-541.

358 DE REU K., RODENBURG T.B., GRIJSPEERDT K., MESSENS W., HEYNDRICKX M., 359 TUYTTENS F., SONCK B., ZOONS J. \& HERMAN L. (2009) Bacteriological contamination, 360 dirt, and cracks of eggshells in furnished cages and noncage systems for laying hens: An 361 international on-farm comparison. Poultry Science, 88: 2442-2448.

362 DONHAM K.J., CUMRO D., REYNOLDS S.J. \& MERCHANT J.A. (2000) Dose-response 363 relationships between occupational aerosol exposures and cross-shift declines of lung function

364 in poultry workers : recommendations for exposure limits. Journal of Occupational and 365 Environmental Medicine, 42: 260-269.

366 DOUWES J., THORNE P., PEARCE N. \& HEEDERIK D. (2003) Bioaerosol health effects and 367 exposure assessment: progress and prospects. Annals of occupational Hygiene, 47: 187-200.

368 ELLEN H.H., AARNINK A., MOSQUERA J., WINKEL A., CAMBRA-LOPEZ M., VAN 369 HARN J. \& OGINK N. (2010) Dust Reduction Options for Poultry Houses. World's Poultry 370 Science Journal, 66: S26.

371 ELLEN H.H., BOTTCHER R.W., VON WACHENFELT E. \& TAKAI H. (2000) Dust levels 372 and control methods in poultry houses. Journal of Agricultural Safety and Health, 6: 275-282.

373 GUSTAFSSON G. \& VON WACHENFELT E. (2006) Airborne Dust Control Measures for 374 Floor Housing System for Laying Hens. VIII Agricultural Engineering International 375 Conference, pp. 1-11.

376 JONES W., MORRING K., OLENCHOCK S.A., WILLIAMS T. \& HICKEY J. (1984)

377 Environmental study of poultry confinement buildings. American Industrial Hygiene 378 Association Journal, 45: 760-766. 
KIRYCHUCK S., DOSMAN J.A., REYNOLDS S.J., WILLSON P., SENTHILSELVAN A., FEDDES J.J.R., CLASSEN H. \& GUENTER W. (2006) Total dust and endotoxin in poultry operations: comparison between cage and floor housing and respiratory effects in workers. Journal of Occupational and Environmental Medicine, 48: 741-748. KIRYCHUCK S., SENTHILSELVAN A., DOSMAN J.A., JUORIO J.A., FEDDES J.J.R., WILSON P., CLASSEN H., REYNOLDS S.J., GUENTER W. \& HURST T.S. (2003) Respiratory symptoms and lung function in poultry confinement workers in Western Canada. Canadian Respiratory Journal, 10: 375-380. LARSSON B.-M., LARSSON K., MALMBERG P., MARTENSSON L. \& PALMBERG L. (1999) Airway responses in naive subjects to exposure in poultry houses : comparison between cage rearing system and alternative rearing system for laying hens. American Journal of Industrial Medicine, 35: 142-149.

LEE S.-A., ADHIKARI A., GRINSHPUN S.A., MCKAY R., SHUKLA R. \& REPONEN T. (2006) Personal exposure to airbone dust and microorganisms in agricultural environments. Journal of Occupational and Environmental Medicine, 3: 118-130.

LYNGTVEIT T. \& EDUARD W. (1997) Reduction of dust exposure by negative air ionisation. Annals of Agricultural and Environmental Medicine, 4: 229-232. MICHEL V. \& HUONNIC D. (2003) A comparison of welfare, health and production performance of laying hens reared in cages or aviaries. British poultry science, 43: 775-776. MITCHELL B.W., HOLT P.S. \& SEO K.H. (2000) Reducing dust in a cage layer room: an electrostatic space charge system. Journal of Applied Poultry Research, 9: 292-296.

400 NIMMERMARK S., LUND V., GUSTAFSSON G. \& EDUARD W. (2009) Ammonia, dust 401 and bacteria in welfare-oriented systems for laying hens. Annals of Agricultural and Environmental Medicine, 16: 103-113. PROTAIS J., QUEGUINER S., BOSCHER E., PIQUET J.C., NADARD B. \& SALVAT G. 404 (2003) Effect of housing systems on the bacterial flora of the air. British Poultry Science, 43: 405 788-789. 
406

407

408

409

410

411

412

413

414

415

416

417

418

419

420

421

422

423

424

425

426

427

428

429

430

RADON K., DANUSER B., IVERSEN M., MONSO E., WEBER C., HARTUNG J., DONHAM K.J., PALMGREN U. \& NOWAK D. (2002a) Air contaminants in different

European farming environments. Annals of Agricultural and Environmental Medicine, 9: 41-48.

RADON K., MONSO E., WEBER C., DANUSER B., IVERSEN M., OPRAVIL U.,

DONHAM K.J., HARTUNG J., PEDERSEN S., GARZ S., BLAINEY D., RABE U. \&

NOWAK D. (2002b) Prevalence and risk factors for airway diseases in farmers - summary of results of the European Farmers' Project. Annals of Agricultural and Environmental Medicine, 9: $207-213$.

RADON K., WEBER C., IVERSEN M., PEDERSEN S. \& NOWAK D. (2001) Exposure assessment and lung function in pig and poultry farmers. Occupational Environmental Medicine, 58: 405-410.

RENSTRÖM A. (2002) Exposure to airborne allergens: a review of sampling methods. Journal of Environmental Monitoring, 4: 619-622.

RYLANDER R. (2002) Endotoxin in the environment - exposure and effects. Journal of Endotoxin Research, 8: 241-252.

RYLANDER R. \& CARVALHEIRO M.F. (2006) Airways inflammation among workers in poultry houses. International Archives of Occupational and Environemental Health, 79: 487490.

SCHENKER M.B., CHRISTIANI D., CORMIER Y., DIMICH-WARD H., DOEKES G., DOSMAN J., DOUWES J., DOWLING K., ENARSON D., GREEN F., HEEDERIK D., HUSMAN K., KULLMAN G., LACASSE Y., LAWSON B., MALMBERG P., MAY J., MCCURDY S., MERCHANT J., MYERS J., NIEUWENHUIJSEN M., OLENCHOCK S., SAIKI C., SCHWARTZ D., SEIBER J., THORNE P., WAGNER G., WHITE N., XU X. \& CHAN-YEUNG M. (1998) Respiratory health hazards in agriculture. American Journal of Respiratory and Critical Care Medicine, 158: S1-S76. 
431 SCHRIEL R., HEISE A., SCHNEIDER F., EICHELSER R., NESER S. \& NOWAK D. (2007)

432 Endotoxin concentration in modern animal houses in Southern Bavaria. Annals of Agricultural 433 and Environmental Medicine, 14: 129-136.

434 SEEDORF J., HARTUNG J., SCHRÖDER M., LINKERT K.H., PHILLIPS V.R., HOLDEN

435 M.R., SNEATH R.W., SHORT J.L., WHITE R.P., PEDERSEN L.J., TAKAI H., JOHNSEN

436 J.O., METZ J.H.M., GROOT KOERKAMP P.W.G., UENK G.H. \& WATHES C.M. (1998)

437 Concentrations and emissions of airbone endotoxins and microorganisms in livestock buildings

438 in Northern Europe. Journal of Agricultural Engineering Research, 70: 97-109.

439 SIMPSON J.C.G., NIVEN R.M., FLETCHER A.M., OLDHAM L.A. \& FRANCIS H.M.

440 (1998a) Prevalence and predictors of work related respiratory symptoms in workers exposed to

441 organic dusts. Occupational Environmental Medicine, 55: 668-672.

442 SIMPSON J.C.G., NIVEN R.M., PICKERING C.A.C., OLDHAM L.A., FLETCHER A.M. \&

443 FRANCIS H.M. (1998b) Comparative personal exposures to organic dusts and endotoxin.

444 Annals of occupational Hygiene, 43: 107-115.

445 TAKAI H., PEDERSEN S., JOHNSEN J.O., METZ J.H.M., GROOT KOERKAMP P.W.G.,

446 UENK G.H., PHILLIPS V.R., HOLDEN M.R., SNEATH R.W., SHORT J.L., WHITE R.P.,

447 HARTUNG J., SEEDORF J., SCHRÖDER M., LINKERT K.H. \& WATHES C.M. (1998)

448 Concentrations and emissions of airborne dust in livestock buildings in Northern Europe.

449 Journal of Agricultural Engineering Research, 70: 59-77.

450 THELIN A., TEGLER O. \& RYLANDER R. (1984) Lung reactions during poultry handling

451 related to dust and bacterial endotoxin levels. European Journal of Respiratory Diseases, 65 :

$452 \quad 266-271$. 


\section{FIGURE LEGENDS}

454

455 Figure 1. Respirable dust concentrations in the ambient air of cage and aviary systems

456 in the experimental trial.

457

458

459 Figure 2. Endotoxin concentrations in the inhalable fraction of dust in different 460 housing systems in the field study. Means are represented by a "plus" and the extreme 461 values depicted by a square are outside the interval defined as the $1^{\text {st }}$ or $3^{\text {rd }}$ quartile \pm 4621.5 interquartile range.

463 
464 Table 1. Characteristics of cage houses and alternative systems monitored in the field 465 study. The median (range) is given for continuous variables.

\begin{tabular}{lccc}
\hline \multirow{2}{*}{$\begin{array}{l}\text { Variable } \\
\text { Cage }\end{array}$} & \multicolumn{2}{c}{ Alternative systems } \\
\cline { 3 - 4 } & & Free-range & Aviary \\
\hline Number of houses studied & 1,426 & 625 & 3 \\
Area $\left(\mathrm{m}^{2}\right)$ & $(1062-1650)$ & $(412-864)$ & $(350-784)$ \\
& 9,600 & 2,040 & 1,600 \\
Volume of the henhouse $\left(\mathrm{m}^{3}\right)$ & $(4400-11700)$ & $(1600-3500)$ & $(1600-5800)$ \\
& 46,400 & 4,600 & 4,700 \\
Housing capacity (hens/house) & $(32000-65000)$ & $(2900-4900)$ & $(4600-16100)$ \\
& 31.9 & 7.9 & 13.6 \\
Density (hens $\left./ \mathrm{m}^{2}\right)$ & $(26.1-54.2)$ & $(5.7-10.7)$ & $(13.1-18.5)$
\end{tabular}

Access to an open-air run (number of houses)

- Yes 10

- No

8

0 3

Ventilation (number of houses)

- Natural

0

10

0

- Forced

8

0

Manure disposal system (number

of houses)

- Manure belts

5

0

3

- Dip pit

3

10

0 
Number of hens per cage 9

(5-60)

\section{6}


1 Table 2. Median (range) of endotoxin concentrations $\left(E U / m^{3}\right)$ of inhalable dust 2 fraction per housing system in the experimental trial.

\begin{tabular}{|c|c|c|c|c|}
\hline Housing & \multicolumn{2}{|c|}{ Ambient air (8 h) } & \multicolumn{2}{|c|}{ Personal exposure $(6 \mathrm{~h})$} \\
\hline system & $\mathrm{n}$ & Concentration & $\mathrm{n}$ & Concentration \\
\hline Cage & 7 & $98(51-470)$ & 3 & $90(88-97)$ \\
\hline Aviaries & 7 & $565(362-1491)$ & 3 & 450 (181-667) \\
\hline
\end{tabular}

3 
1 Table 3. Respirable dust and endotoxin concentrations (median and range) in the

2 inhalable dust fraction in laying houses for each housing system in the field study

\begin{tabular}{|c|c|c|c|}
\hline Housing system & $\mathrm{n}^{1}$ & $\begin{array}{l}\text { Respirable dust concentration } \\
\qquad\left(\mathrm{mg} / \mathrm{m}^{3}\right)\end{array}$ & $\begin{array}{l}\text { Endotoxin concentration } \\
\qquad\left(\mathrm{EU} / \mathrm{m}^{3}\right)\end{array}$ \\
\hline Cage & 15 & $0.125(0.000-0.264)$ & $204(78-576)$ \\
\hline Alternative & 21 & $0.438(0.020-2.850)$ & $684(35-3156)$ \\
\hline - Free-range & 18 & $0.386(0.020-1.010)$ & $669(35-3156)$ \\
\hline - Aviary & 3 & $1.200(0.825-2.850)$ & $771(465-1543)$ \\
\hline$P^{2}$ & & $<0.01$ & $<0.01$ \\
\hline
\end{tabular}

$3{ }^{\mathrm{T}}$ Number of measures.

$4 \quad{ }^{2}$ Probability for the Kruskal Wallis test for comparison of cage and alternative housing 5 systems. 
1 Table 4. Respirable dust concentrations and endotoxin concentrations in the inhalable

2 dust fraction in laying houses for each season in the field study (median and range)

3

\begin{tabular}{|c|c|c|c|}
\hline Season & $\mathrm{n}^{1}$ & $\begin{array}{l}\text { Respirable dust concentration } \\
\qquad\left(\mathrm{mg} / \mathrm{m}^{3}\right)\end{array}$ & $\begin{array}{c}\text { Endotoxin concentration } \\
\qquad\left(\mathrm{EU} / \mathrm{m}^{3}\right)\end{array}$ \\
\hline Autumn/winter & 15 & $\begin{array}{c}0.189 \\
(0.000-0.599)\end{array}$ & $\begin{array}{c}320 \\
(135-1822)\end{array}$ \\
\hline Spring/summer & 15 & $\begin{array}{c}0.143 \\
(0.000-0.733)\end{array}$ & $\begin{array}{c}385 \\
(35-2329)\end{array}$ \\
\hline$P^{2}$ & & 0.55 & 0.65 \\
\hline${ }^{1}$ Number of mea & ures & & \\
\hline
\end{tabular}

52 Probability for the Wilcoxon test for comparison between seasons 
Figure 1

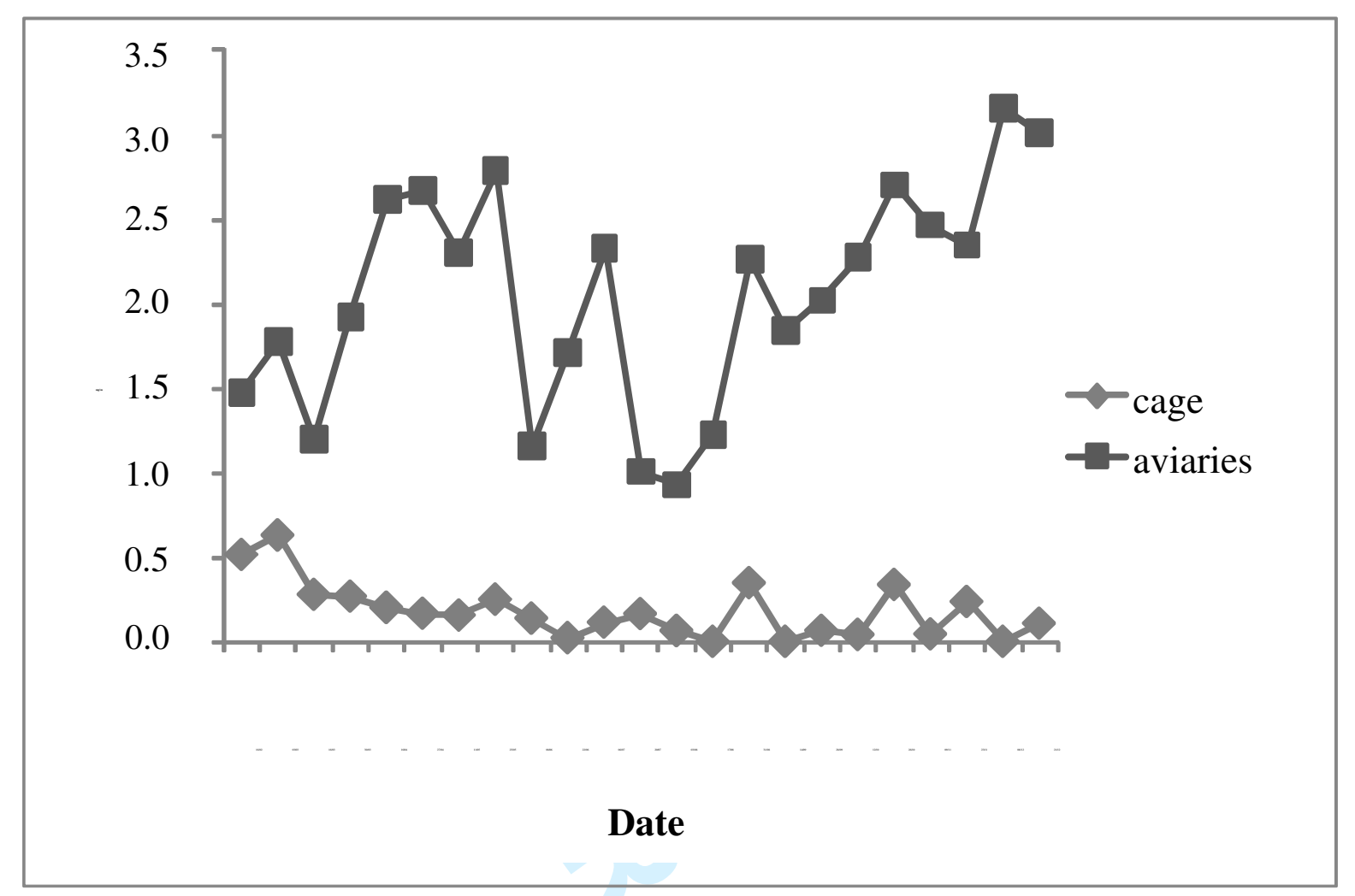




\section{Figure 2}

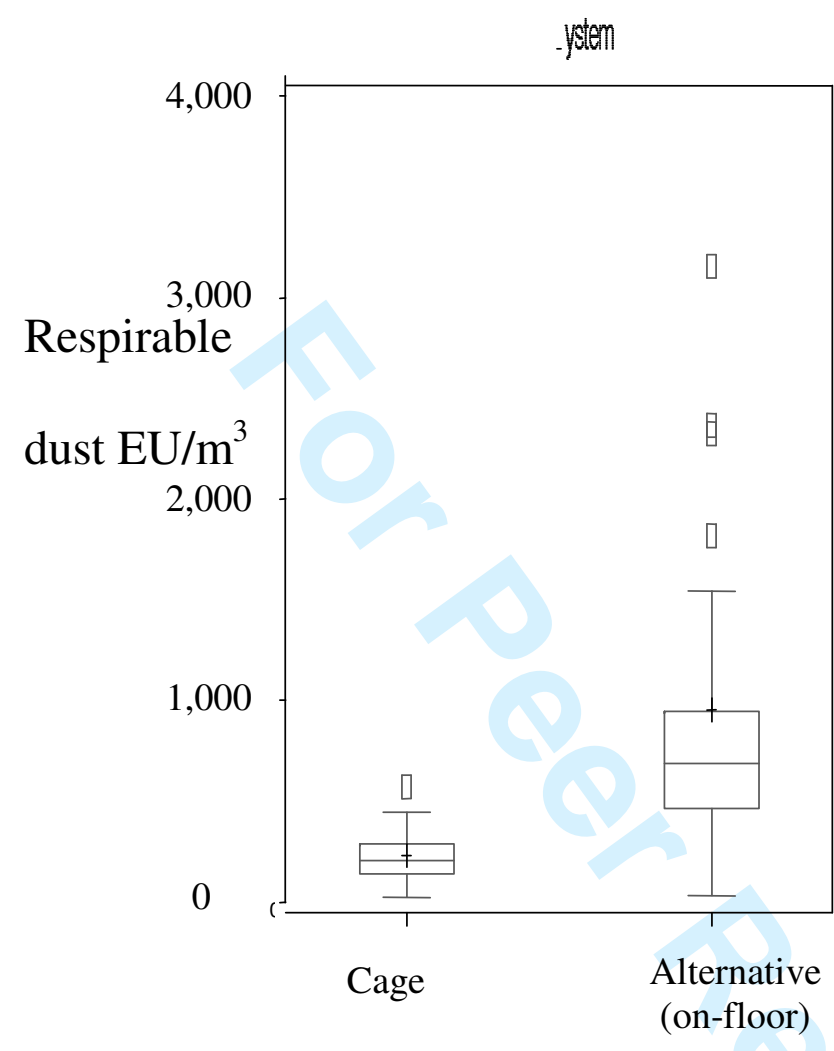

